the physiology of eggs and spermatozoa, and we practitioners will find much in the chapters on the vitamins, mammary gland and endocrines to clarify our ideas of the intricate inter-relationships of the various factors. Here we have a detailed and up-to-date survey of the whole subject in one volume and we owe a great debt to Prof. Allen and his co-workers for achieving this for us in so masterly a manner.

\section{THE BRITISH}

\section{ENCYCLOP EDIA OF MEDICAL}

\section{PRACTICE. Vol. XII. (TETANUS TO YELLOW FEVER.)}

Edited by SIR HuMpHry ROLIESTON BT. Butterworth \& Co. 1939. Price 35s. Od.

This, the final volume of this most excellent Encyclopædia of Medicine, is specially interesting not only because it completes the series but also because of its intrinsic value. It would almost seem as if fate had ordained its publication at this particular moment, since it appears just on the outbreak of war and deals with several subjects of peculiar military interest. Among these we would mention tetanus, trench fever, veldt sore, the typhus fevers and undulant fever, all of which have been, and which mayhap will be again scourges of our armies in the field. These conditions have been allotted to such well-known authorities as Dr. Knott, Major-General Sir John Megaw, Dr. Craib, and Lieut.-General Sir W. P. MacArthur. But these titles do not exhaust the list of even topical subjects considered in the volume. For instance, of interest both in peace and in war, is the subject of industrial poisoning which is dealt with at length by Dr. Donald Hunter. Poisoning in general is discussed by Dr. Roche Lynch.

Of more perennial interest there are full discussions of the deformities and diseases of the uterus by the late Sir Robert Thurstone, Sir Beckwith Whitehouse and Drs. Arthur Gemmell and W. Fletcher Shaw; vitamins by Dr. Leslie Harris; examination of the urine by Dr. T. Douglas Robertson; uræmia by Dr. Izod Bennett; and tuberculosis by Drs. Gloyne, Morland and Clifford Hoyle.

The publishers make a most important announcement in this volume. They state that,

"Although this is the last volume of the Encyclopædia, it is to be followed by annual supplements designed to keep the whole work up to date.

The first supplement, consisting of two volumes, is in active preparation and will be published shortly. Volume 1 will contain new information which has been suggested in many cases by the original contributors, and will be arranged on the well-known Butterworth keyed supplementary system, which facilitlates rapid reference from the original contributions to the new material. Volume II will contain, firstly, a series of critical surveys on the present position and possible developments of various branches of medicine, surgery, and the specialties, and secondly, abstracts from the world's medical literature covering the whole field of medicine."

This information should be particularly gratifying to all who have already subscribed for the work and should also be an inducement to those who do not possess it to subscribe even at this late date, for such a plan will ensure that the work will not readily become out of date. Indeed, if the supplements maintain the high standard of the original volumes, the work will be the ready book of reference throughout the whole field of medicine during their whole professional life.

\section{CFSARIAN SECTION : LOWER SEGMENT OPERATION.}

By C.McIntosh Marshall, F.R.C.S., Hon. Asst. Surgeon, Liverpool Maternity Hospital, etc. Pp. 223 and illustrated. John Wright \& Sons Ltd. Bristol. Price 21s. Od.

This book is a most welcome addition to the obstetrician's library. It is a complete and careful survey of the operation from every standpoint, and from it the author has developed a technique which in his hands has given remarkable results.

After an anatomical and historical introduction to the subject, a clear and detailed description of the operation is given, the text being made still more lucid by a large number of excellent illustrations. Anæsthesia has a chapter to itself, and it is good to see the advantages of local anæsthesia stressed, although the claims of others are fairly discussed. The chapter on Dangers and Mishaps is typical of the critical manner in which the author is prepared to discuss every advantage and disadvantage of the operation, and though an enthusiast himself, he is not blind to the dangers even of the lower segment operation. The book is founded on a series of 246 cases, with no maternal and only five per cent. fœtal mortality, which certainly speaks for itself. It is a book by an obstetrician for obstetricians.

\section{STERILITY AND IMPAIRED FERTILITY.}

By CEDRIC LANe-Roberts, M.S., F.R.C.S., F.R.C.O.G., A I B E R T SHARMAN, M.D., M.R.C.O.G., KENNETH WALKER, F.R.C.S., and B. P. Wiesner, D.Sc., Ph.D., F.R.S.E. Pp. 412 and illustrated. Hamish Hamilton, Ltd., London. Price 14s. Od.

The problem of the infertile marriage is one of increasing importance in view of the modern tendency to limit families for economic and other reasons in healthy fertile people. Even 
more so is it a problem to those endeavouring to mitigate the social and psychical effect of sterility on those unhappy couples who would give anything to have children. Any contribution, therefore, which will help towards an understanding of the condition must be regarded as doubly valuable, and a great advance in the subject has been made by the authors of this book.

A brief survey of the work will show the great complexity of the subject, and the reasons for the ill-success of treatment in the past become apparent. The book is divided into male and female sections, and in both the anatomy, physiology and psychology is fully and clearly explained. Then come the pathological factors at work, and finally the investigation and treatment. Numerous illustrations add to the value of the book, and with its aid the practitioner should be able easily to determine the type of sterility with which he is dealing, though the complete elucidation and cure may be a more difficult matter. More than anything else, the book shows the great need for a centre where biopsies, urinary and sperm tests can be made and treatment given at a reasonable price. It is the enormous cost of these investigations which is the great bar to progress, and it is splendid news that a committee is already in being to discuss the matter.

\section{THE PRACTITIONERS POCKET-BOOK.}

By D. S. Davies, D.M. (Oxon), F.R.C.S. (Edin.). John Bale Medical Publications. 1939. Price 7s. 6d.

Well adapted for the pocket, and provided with useful blank interleaves, this is essentially a fund of reminders for the busy practitioner. The field it covers in its 266 small pages is immense and the necessarily brief statements are in consequence dogmatic. A good example is under Thyrotoxicosis, where one reads "Look to septic foci and always do tonsillectomy"'. Some statements might be better expressed and one doubts whether everyone will receive much help from "In children, no temperature, pulse or blood count rules out appendicitis'" More serious errors are the blood urea figure given on page 28 , and the omission of the gall bladder when enumerating tumours under Acute Abdomen.

But it is always easy to find fault and it is better to point out that we have here a most useful mass of information dealing with diagnosis and treatment. The section dealing with PostOperative complications is worthy of praise; as is also Appendix II, Medicinal Preparations, though here it may be hoped that more information regarding dosage and indications for use will be included in a future edition.

\section{Forthcoming Medical Books.}

EDWARD ARNOLD \& CO., 41 \& 43, Maddox Street, London, W.1. "Neurology," by the late S. A. Kinnier Wilson, M.D., B.Sc. (Edin.), F.R.C.P., Physician for Out-Patients, National Hospital, Queen Square; Neurologist, King's College Hospital. Edited by A. Ninian Bruce, F.R.C.S. (Edin.), D.Sc. (Edin.), M.D., F.R.C.P. (Edin.), Lt.-Col. R.A.M.C. Two volumes, lxiv +1840 pages, 332 illustrations. $£ 4$ 4s. net. January.

J. B. LIPPINCOTT COMPANY,

16, John Street, Adelphi, W.C.2.

"Modern Surgical Technic," by Max Thorek, M.D., K.L.H. (France); K.O. (Italy). Complete in 3 volumes with 2,174 illustrations. Price $£ 7$ 10s. Od. With a Foreword by Donald C. Balfour, M.B., M.D. (Tor.), Ll.D.

"Surgical Pathology of the Diseases of the Mouth and Jaws," by Arthur E.
Hertzler, M.D. 206 Illustrations. 264 Pages. Price 21s. Od.

"Functional Disorders of the Foot: Their Diagnosis and Treatment," by Frank D. Dickson, M.D. and Rex L. Diveley, M.D. 202 Illustrations. Index. 305 Pages. Price 21s. 0d.

"The Art of Ancesthesia," by Paluel J. Flagg, M.D. Sixth Revised Edition. 161 Illustrations. Index. 491 Pages. Price 30s. 0d.

"Treatment by Diet," by Clifford J. Barborka, B.S., M.S. Fourth Revised Edition. Illustrated. 642 Pages. Price 25s. Od.

"Practical Bandaging," by Eldridge L. Eliason, M.D. Fifth Edition. 150 Illustrations. 156 Pages. Price 7s. 6d.

"Spinal Ancesthesia," by Louis H. Maxson, M.D. 69 Illustrations. 409 Pages. Price 30s. 0d. 